\title{
Reconfigurable Four Component Molecular Switch Based on pH-Controlled Guest Swapping
}

\section{Supporting Information}

Sriparna Chakrabarti ${ }^{\dagger}$, Pritam Mukhopadhyay ${ }^{\dagger}$, Shirley Lin ${ }^{\ddagger}$ and Lyle Isaacs ${ }^{\dagger} *$

${ }^{\dagger}$ Department of Chemistry and Biochemistry, University of Maryland, College Park, MD 20742

${ }^{\ddagger}$ Department of Chemistry, United States Naval Academy, 572 Holloway Rd, Annapolis, Maryland 21402

Table of Contents

Experimental procedures and characterization

Sample preparation for 3 and 4 component mixtures and control experiments

Chart S1. Structures of compounds depicted in SI

Figure S1. Spectra for individual components 1 and 2

Figure S2. Spectra at different $\mathrm{pH}$ of mixture of $\mathrm{CB}[6], \beta-\mathrm{CD}, \mathbf{1}$ and $\mathbf{2}$

Figure S3. Spectra for components $\mathbf{3}, \mathbf{4}$ and complexes $\mathrm{CB}[6] \bullet \mathbf{3}$ and

$$
\mathrm{CB}[6] \bullet 4
$$

Figure S4. Spectra at different $\mathrm{pH}$ of mixture of $\mathrm{CB}[6], 3$ and 4

Figure S5. Spectra at different $\mathrm{pH}$ of mixture of $\mathrm{CB}[6], 1$ and 2

Figure S6. Spectra at different $\mathrm{pH}$ of mixture of $\beta-\mathrm{CD}, \mathbf{1}$ and 2

Figure S7 - S9. Additional Gepasi simulations of the system Reported in Figure 5
S9

S10

Pages

$\mathrm{S} 2$

S3

S4

S5

S6

S7

S8

S11-S13

Figure S10. Gepasi simulations designed to mimic the experimental system comprising $\mathrm{CB}[6], \beta-\mathrm{CD}, \mathbf{1}$, and $\mathbf{2}$ 


\section{Experimental Procedures and Characterization.}

General Experimental. Starting materials and $\beta-C D$ were purchased from commercial suppliers and were used without further purification. $\mathrm{CB}[6]$ and $\mathbf{1}$ were prepared according to the literature procedures. ${ }^{1}$ Melting points were measured in open capillary tubes and are uncorrected. NMR spectra were measured on spectrometers operating at 400 or $500 \mathrm{MHz}$ for ${ }^{1} \mathrm{H}$ and 100 or $125 \mathrm{MHz}$ for ${ }^{13} \mathrm{C}$. All spectra are referenced relative to external $\left(\mathrm{CD}_{3}\right)_{3} \mathrm{SiCD}_{2} \mathrm{CD}_{2} \mathrm{CO}_{2} \mathrm{D}$. Mass spectrometry was performed using a magnetic sector instrument by fast atom bombardment (FAB) using the indicated matrix. The matrix "magic bullet" is a 5:1 (w:w) mixture of dithiothreitol:dithioerythritol.

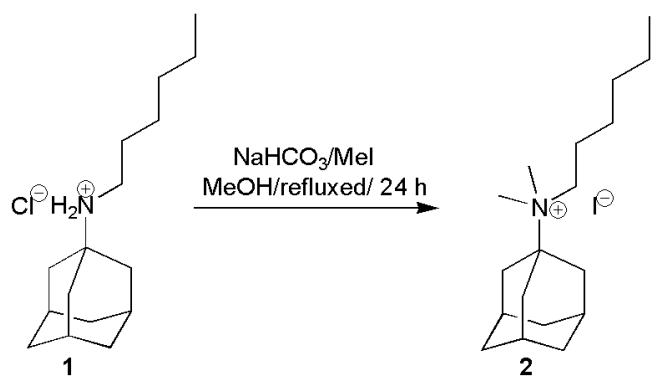

Compound 2. To a solution of 1 adamantanylhexylammonium chloride (1) $(1.00 \mathrm{~g}, 4.25$ mmol) in $\mathrm{CH}_{3} \mathrm{OH}(15 \mathrm{~mL})$, oven-dried $\mathrm{NaHCO}_{3}(1.78 \mathrm{~g}$, $21.3 \mathrm{mmol})$ was added followed by $\mathrm{CH}_{3} \mathrm{I}(1.32 \mathrm{~mL}, 3.02$ $\mathrm{g}, 21.3 \mathrm{mmol})$ and the reaction mixture was refluxed for $24 \mathrm{~h}$. The solvent was evaporated, $\mathrm{CHCl}_{3}(100 \mathrm{~mL})$ was added to the residue, the mixture was filtered, and the

filtrate was evaporated. The crude solid was recrystallized from $\mathrm{CHCl}_{3} / \mathrm{Et}_{2} \mathrm{O}$ to afford $\mathbf{2}$ as a white solid $(1.41 \mathrm{~g}, 3.61 \mathrm{mmol}, 85 \%)$. Mp 173-174 ${ }^{\circ} \mathrm{C}$. IR $\left(\mathrm{KBr}, \mathrm{cm}^{-1}\right): 3006 \mathrm{w}, 2948 \mathrm{~s}, 2918 \mathrm{~s}$, 2856s, 1477m, 1456m. ${ }^{1} \mathrm{H}$ NMR (400 MHz, $\mathrm{D}_{2} \mathrm{O}$ ): $\delta 3.30-3.20(\mathrm{~m}, 2 \mathrm{H}), 2.87$ (s, 6H), 2.32 (br. s, $3 \mathrm{H}), 2.10$ (br. s, 6H), 1.80-1.60 (m, 8H), 1.45-1.30 (m, 6H), $0.89(\mathrm{t}, J=6.9,3 \mathrm{H}) .{ }^{13} \mathrm{C}$ NMR $(100$ $\mathrm{MHz}, \mathrm{D}_{2} \mathrm{O}, 1$,4-dioxane as ext. reference): $\delta 75.1,57.7,43.0,34.7,34.3,30.7,30.3,25.6,22.5$, 21.8, 13.3. MS (FAB, Magic Bullet): $m / z 264\left(100,[\mathrm{M}-\mathrm{I}]^{+}\right)$. HR-MS (FAB, Magic Bullet/PEG): $m / z 264.2689$ ([M - I $]^{+}, \mathrm{C}_{18} \mathrm{H}_{34} \mathrm{~N}$, calcd 264.2691).

Sample preparation for three component mixtures of $\mathrm{CB}[6], 3$, and 4. Three component mixtures comprising $\mathrm{CB}[6], \mathbf{3}$, and $\mathbf{4}$ were prepared as follows: (i) $\mathrm{CB}[6]$ (10.8 $\mathrm{mg}$ ) was weighed out in a $5 \mathrm{~mL}$ screw cap vial. (ii) A solution of 3 in $\mathrm{D}_{2} \mathrm{O}(10 \mathrm{mM}, 1.2 \mathrm{~mL})$ was added. (iii) $\mathrm{A}$ solution of 4 in $\mathrm{D}_{2} \mathrm{O}(10 \mathrm{mM}, 1.2 \mathrm{~mL})$ was added. (iv) A solution of $\mathrm{Na}_{2} \mathrm{SO}_{4}$ in $\mathrm{D}_{2} \mathrm{O}(20 \mathrm{mM}, 1.6$ $\mathrm{mL}$ ) was added. (v) The mixture was sonicated and vortexed to afford a homogeneous solution (4 mL) of CB[6]:3:4 (2.5 mM:3 mM:3 mM; 1:1.2:1.2 equiv.) in $8 \mathrm{mM} \mathrm{Na}_{2} \mathrm{SO}_{4}$. (vi) The $\mathrm{pD}$ of the solution was adjusted to 7.0 with dilute KOD and $\mathrm{DCl}$ solutions. (vii) Portions of this solution $(0.5 \mathrm{~mL})$ were taken into separate vials and their $\mathrm{pD}$ was adjusted subsequently to 8.0 , 9.0, 10.0, 11.0, 12.0 and 13.0 with dilute KOD and DCl solutions. (viii) The solutions were transferred to NMR tubes for spectral analysis at pD 7.0 - 13.0.

Sample preparation for four component mixtures of $\mathrm{CB}[\mathbf{6}], \boldsymbol{\beta}-\mathrm{CD}, \mathbf{1}$ and 2 . Four component mixtures comprising $\mathrm{CB}[6], \beta-\mathrm{CD}, \mathbf{1}$, and $\mathbf{2}$ were prepared as follows: (i) $\mathrm{CB}[6]$ (5.4 $\mathrm{mg}$ ) was weighed out in a $5 \mathrm{~mL}$ screw cap vial. (ii) A solution of $\mathbf{1}$ in $\mathrm{D}_{2} \mathrm{O}(10 \mathrm{mM}, 0.5 \mathrm{~mL})$ was added. 
(iii) A solution of $\mathrm{Na}_{2} \mathrm{SO}_{4}$ in $\mathrm{D}_{2} \mathrm{O}(20 \mathrm{mM}, 0.8 \mathrm{~mL})$ was added, (iv) $\mathrm{D}_{2} \mathrm{O}(0.7 \mathrm{~mL})$ was added, (v) the mixture was sonicated and vortexed to afford a homogeneous solution (2 mL) (Solution A) of $2.5 \mathrm{mM}$ : $2.5 \mathrm{mM}$ (1:1equiv.) of $\mathrm{CB}[6]: 1$ in $8 \mathrm{mM} \mathrm{Na}_{2} \mathrm{SO}_{4}$. (vi) The $\mathrm{pD}$ of the solution (A) was adjusted to 7.0 with dilute $\mathrm{KOD}$ and $\mathrm{DCl}$ solution. In a separate $5 \mathrm{~mL}$ screw cap vial, (vii) 5.6 $\mathrm{mg}$ of $\beta$-CD was weighed out, (viii) $10 \mathrm{mM}(0.5 \mathrm{~mL})$ solution of 2 in $\mathrm{D}_{2} \mathrm{O}$ was added, (ix) 20 $\mathrm{mM}(0.8 \mathrm{~mL}) \mathrm{Na}_{2} \mathrm{SO}_{4}$ solution in $\mathrm{D}_{2} \mathrm{O}$ was added, $(\mathrm{x}) \mathrm{D}_{2} \mathrm{O}(0.7 \mathrm{~mL})$ was added, (xi) the mixture was sonicated and vortexed to afford a homogeneous solution $(2 \mathrm{~mL})$ (Solution $\mathbf{B})$ of $2.5 \mathrm{mM}$ : $2.5 \mathrm{mM}$ (1:1 equiv.) of $\beta-\mathrm{CD}: 2$ in $8 \mathrm{mM} \mathrm{Na}_{2} \mathrm{SO}_{4}$. (xii) The $\mathrm{pD}$ of the solution (B) was adjusted to 7.0 with dilute KOD and DCl solution. (xiii) Equal volumes of solutions $\mathbf{A}$ and $\mathbf{B}$ were mixed in a separate vial and, (xiv) $0.5 \mathrm{~mL}$ portions of this solution were taken into separate vials and their pD was adjusted subsequently to 8.0, 9.0, 10.0, 11.0, 12.0 and 13.0 with dilute KOD and DCl solutions, (xv) the solutions were transferred to NMR tubes for spectral analysis.

Sample preparation for control experiments. Samples for the various control experiments were prepared as follows: (i) A solution of 3 in $\mathrm{D}_{2} \mathrm{O}(2.5 \mathrm{mM}, 4 \mathrm{~mL})$ was prepared and the $\mathrm{pD}$ of the solution was adjusted to 7.0 with dilute KOD and $\mathrm{DCl}$ solutions. Portions of this solution $(0.5 \mathrm{~mL})$ were transferred into separate vials and their $\mathrm{pD}$ was adjusted subsequently to $8,9,10$, 11,12 and 13 with dilute KOD and DCl solutions and, the solutions were transferred to NMR tube for spectral analysis at pD 7.0-13.0. (ii) Similarly, a solution of 4 in $\mathrm{D}_{2} \mathrm{O}(2.5 \mathrm{mM})$ was prepared and spectra recorded after adjustment to the appropriate $\mathrm{pD}$ with dilute $\mathrm{DCl}$ or $\mathrm{NaOD}$ ( $\mathrm{pD} 7.0-\mathrm{s} 13.0)$. Following the same procedure, solutions of $\mathbf{1}$ and $\mathbf{2}$ in $\mathrm{D}_{2} \mathrm{O}(1.25 \mathrm{mM})$ were prepared and their spectra recorded at $\mathrm{pD} 7.0-13.0$. (iii) $\mathrm{CB}[6]$ (10.8 $\mathrm{mg}$ ) was weighed out in a 5 $\mathrm{mL}$ screw cap vial, a solution of 3 in $\mathrm{D}_{2} \mathrm{O}(10 \mathrm{mM}, 1.2 \mathrm{~mL})$ was added, a solution of $\mathrm{Na}_{2} \mathrm{SO}_{4}$ in $\mathrm{D}_{2} \mathrm{O}(20 \mathrm{mM}, 1.6 \mathrm{~mL})$ was added, the mixture was sonicated and vortexed to afford a homogeneous solution (4 mL) containing $\mathrm{CB}[6]$ and $3(2.5 \mathrm{mM}: 3 \mathrm{mM})$ in $8 \mathrm{mM} \mathrm{Na} \mathrm{SO}_{4}$. The $\mathrm{pD}$ of the solution was adjusted to 7.0 with dilute $\mathrm{KOD}$ and $\mathrm{DCl}$ solution. Portions $(0.5 \mathrm{~mL})$ of this solution were transferred into separate vials and their $\mathrm{pD}$ was adjusted subsequently to 8.0, 9.0, 10.0, 11.0, 12.0 and 13.0 with dilute KOD and DCl solutions. The solutions were then transferred to NMR tubes for spectral analysis. (iv) Similarly, a solution of CB[6] and 4 (2.5 $\mathrm{mM}: 3 \mathrm{mM})$ in $8 \mathrm{mM} \mathrm{Na}_{2} \mathrm{SO}_{4}$ in $\mathrm{D}_{2} \mathrm{O}$ was prepared and spectra recorded at pD $7.0-13.0$. Following the same procedure, solutions of $\mathrm{CB}[6]: 1, \mathrm{CB}[6]: 2, \beta-\mathrm{CD}: \mathbf{1}$ and $\beta-\mathrm{CD}: 2$ (1.25 mM:1.5 $\mathrm{mM}$ ) were prepared in $8 \mathrm{mM} \mathrm{Na}_{2} \mathrm{SO}_{4}$ in $\mathrm{D}_{2} \mathrm{O}$ and their spectra recorded at $\mathrm{pD} 7.0-13.0$. (v) Similarly, solutions of CB[6]:1:2 and $\beta-C D: 1: 2(1.25 \mathrm{mM}: 1.25 \mathrm{mM}: 1.25 \mathrm{mM})$ were prepared in $8 \mathrm{mM} \mathrm{Na}_{2} \mathrm{SO}_{4}$ in $\mathrm{D}_{2} \mathrm{O}$ and their spectra recorded at $\mathrm{pD} 7.0-13.0$.

\section{References:}

1) Day, A.; Arnold, A. P.; Blanch, R. J.; Snushall, B. J. Org. Chem. 2001, 66, 8094-8100.

Mukhopadhyay, P.; Zavalij, P. Y.; Isaacs, L. J. Am. Chem. Soc. 2006, 128, 14092-14102. 

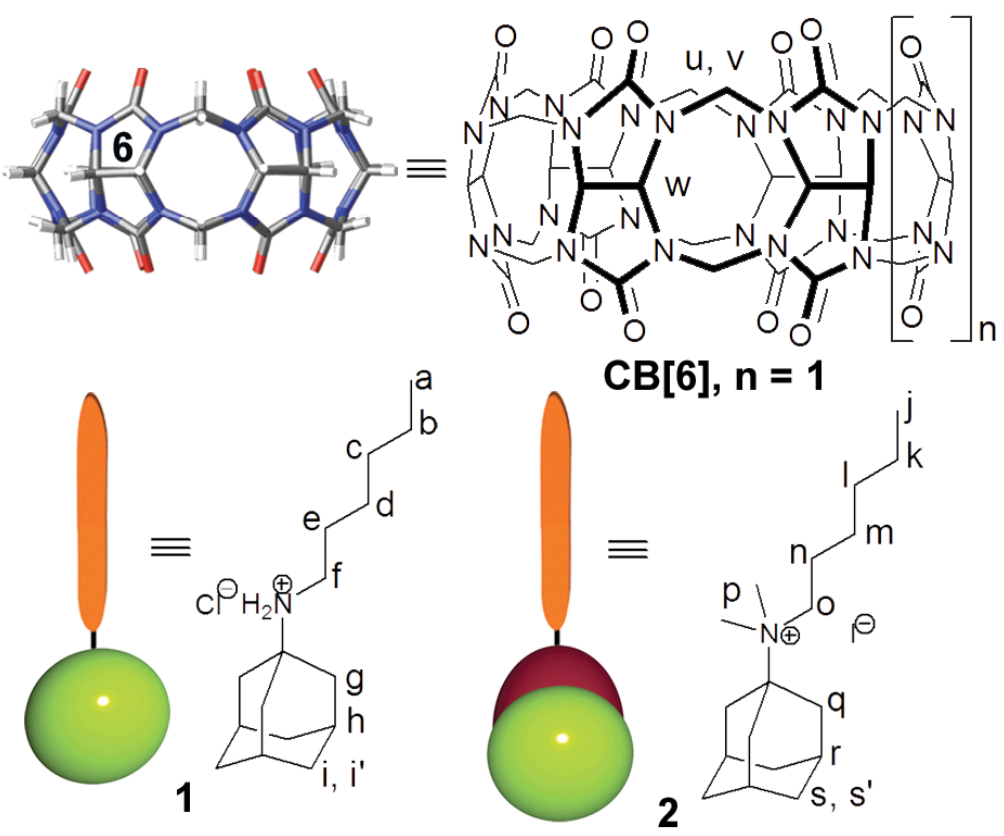

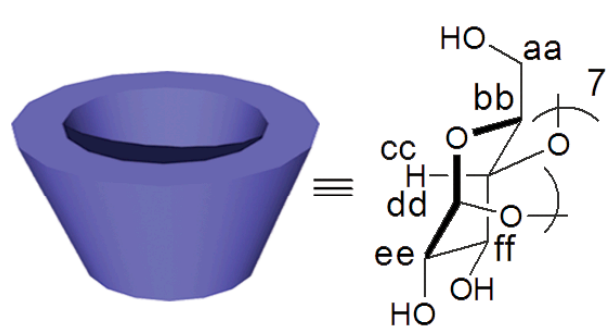

$\beta-C D$
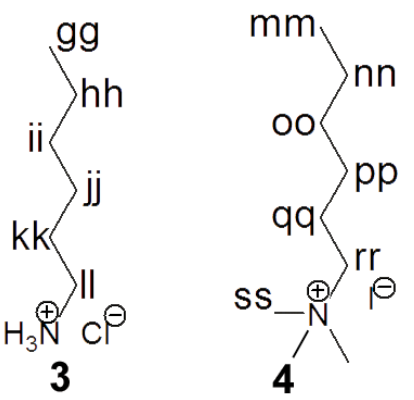

Chart S1. Structures of compounds represented in Figures S1-S6 and the labeling scheme for their ${ }^{1} \mathrm{H}$ NMR resonances. 

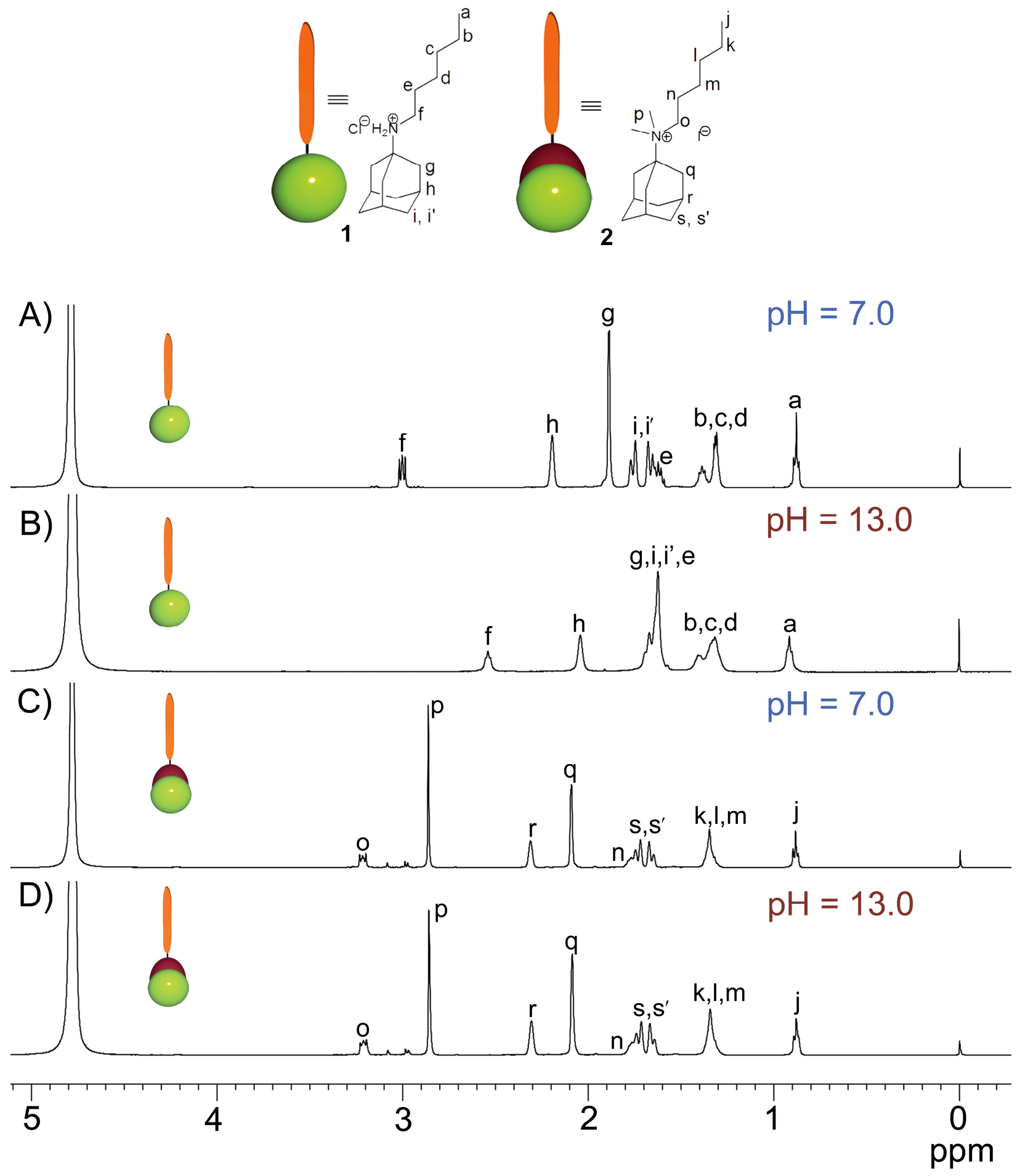

Figure S1. ${ }^{1} \mathrm{H}$ NMR spectra (400 MHz, $\mathrm{D}_{2} \mathrm{O}, 298 \mathrm{~K}, 1.25 \mathrm{mM}$ components) recorded for the individual components $\mathbf{1}$ and $\mathbf{2}$ at $\mathrm{pH} 7.0$ and 13.0: A) 1 at $\mathrm{pH}$ 7.0, B) 1 at $\mathrm{pH} 13.0, \mathrm{C}) \mathbf{2}$ at $\mathrm{pH}$ 7.0, D) 2 at $\mathrm{pH} 13.0$. 

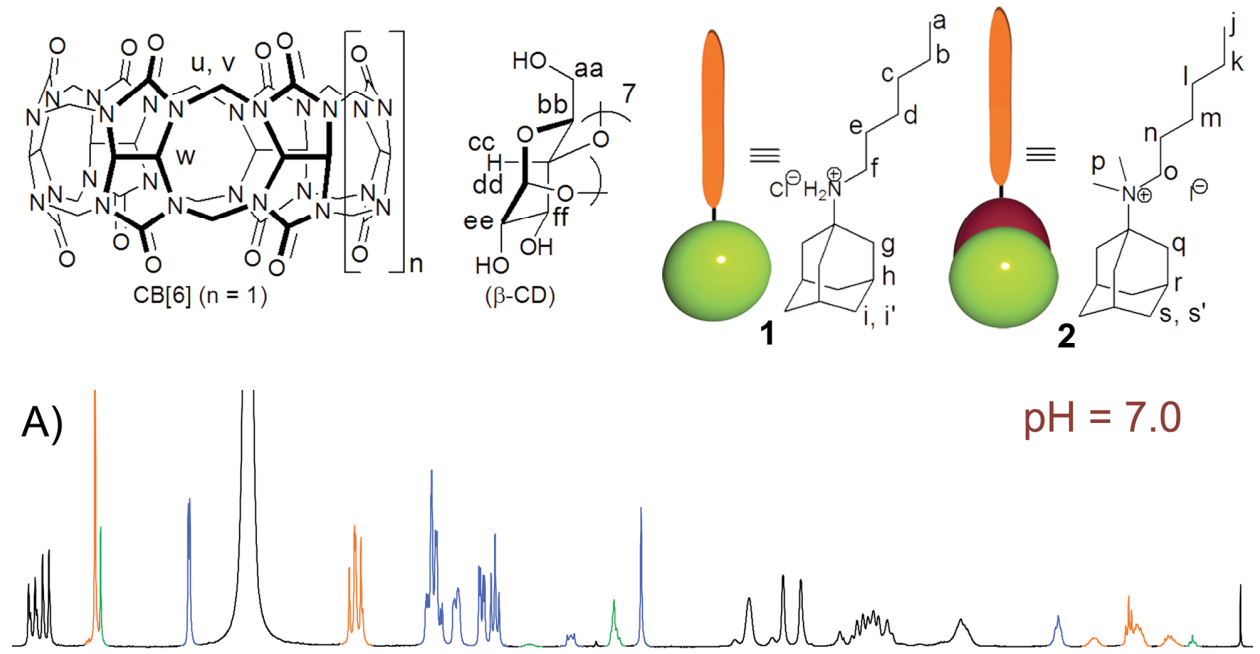

$\mathrm{pH}=7.0$

B)
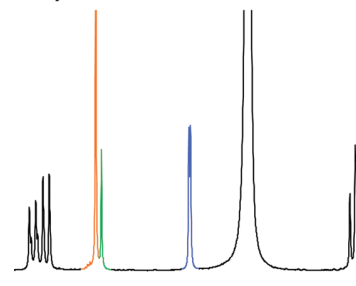

$\mathrm{pH}=10.0$
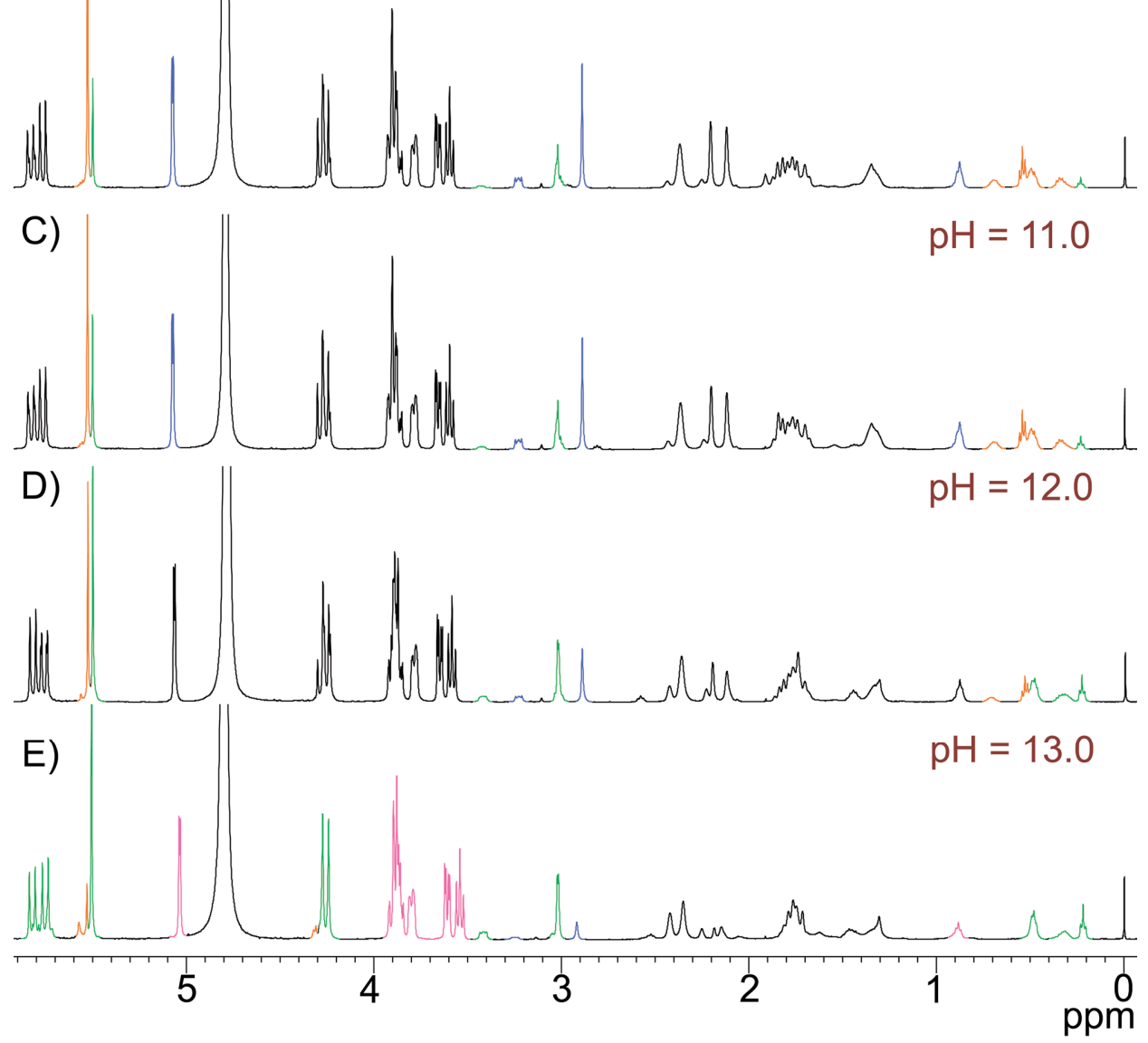

Figure S2. ${ }^{1} \mathrm{H}$ NMR spectra (400 MHz, $\mathrm{D}_{2} \mathrm{O}, 298 \mathrm{~K}, 1.25 \mathrm{mM}$ components in $8 \mathrm{mM} \mathrm{Na}_{2} \mathrm{SO}_{4}$ ) recorded for an equimolar mixture of $\mathrm{CB}[6], \beta-\mathrm{CD}, 1$ and 2: A) at $\mathrm{pH} 7.0, \mathrm{~B}$ ) at $\mathrm{pH} 10.0, \mathrm{C}$ ) at $\mathrm{pH} 11.0, \mathrm{D})$ at $\mathrm{pH} 12.0, \mathrm{E})$ at $\mathrm{pH}$ 13.0. 


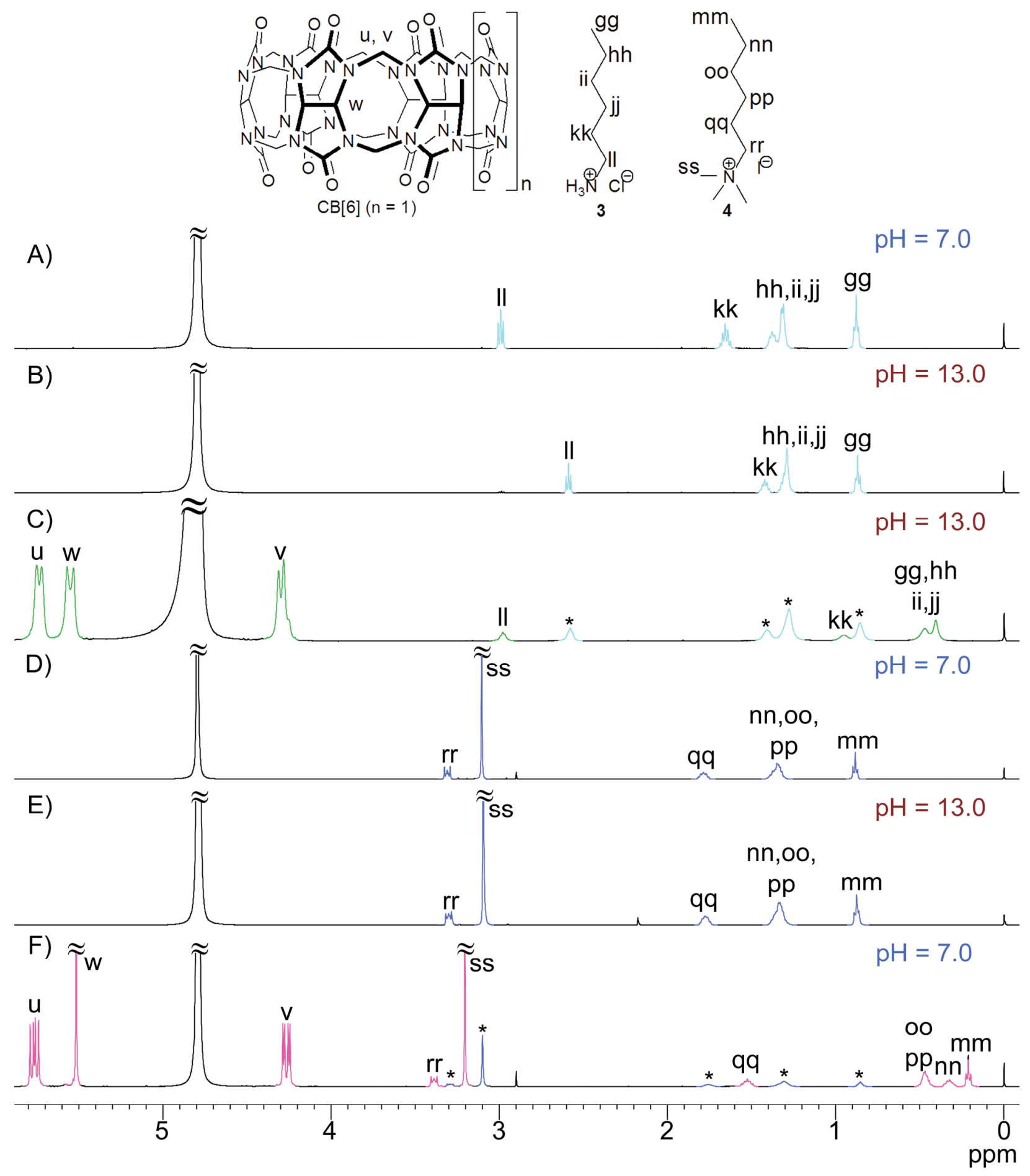

Figure S3. ${ }^{1} \mathrm{H}$ NMR spectra (400 MHz, $\left.\mathrm{D}_{2} \mathrm{O}, 298 \mathrm{~K}\right)$ recorded for individual components 3 and 4 at $\mathrm{pH} 7.0$ and 13.0 and the host-guest complexes: A) $\mathbf{3}$ at $\mathrm{pH} 7.0(2.5 \mathrm{mM}), \mathrm{B}) \mathbf{3}$ at $\mathrm{pH} 13.0$ (2.5 mM), C) $\mathrm{CB}[6] \bullet 3$ at $\mathrm{pH} 13.0$ (2.5 mM: $3 \mathrm{mM}$ in $8 \mathrm{mM} \mathrm{Na}_{2} \mathrm{SO}_{4}$ solution), D) 4 at $\mathrm{pH} 7.0$ (2.5 $\mathrm{mM})$, E) 4 at $\mathrm{pH} 13.0(2.5 \mathrm{mM}), \mathrm{F}) \mathrm{CB}[6] \bullet 4$ at $\mathrm{pH} 7.0\left(2.5 \mathrm{mM}: 3 \mathrm{mM}\right.$ in $8 \mathrm{mM} \mathrm{Na}_{2} \mathrm{SO}_{4}$ solution). ['*'-mark indicates resonances due to unbound $\mathbf{3}$ and $\mathbf{4}$ ]. 

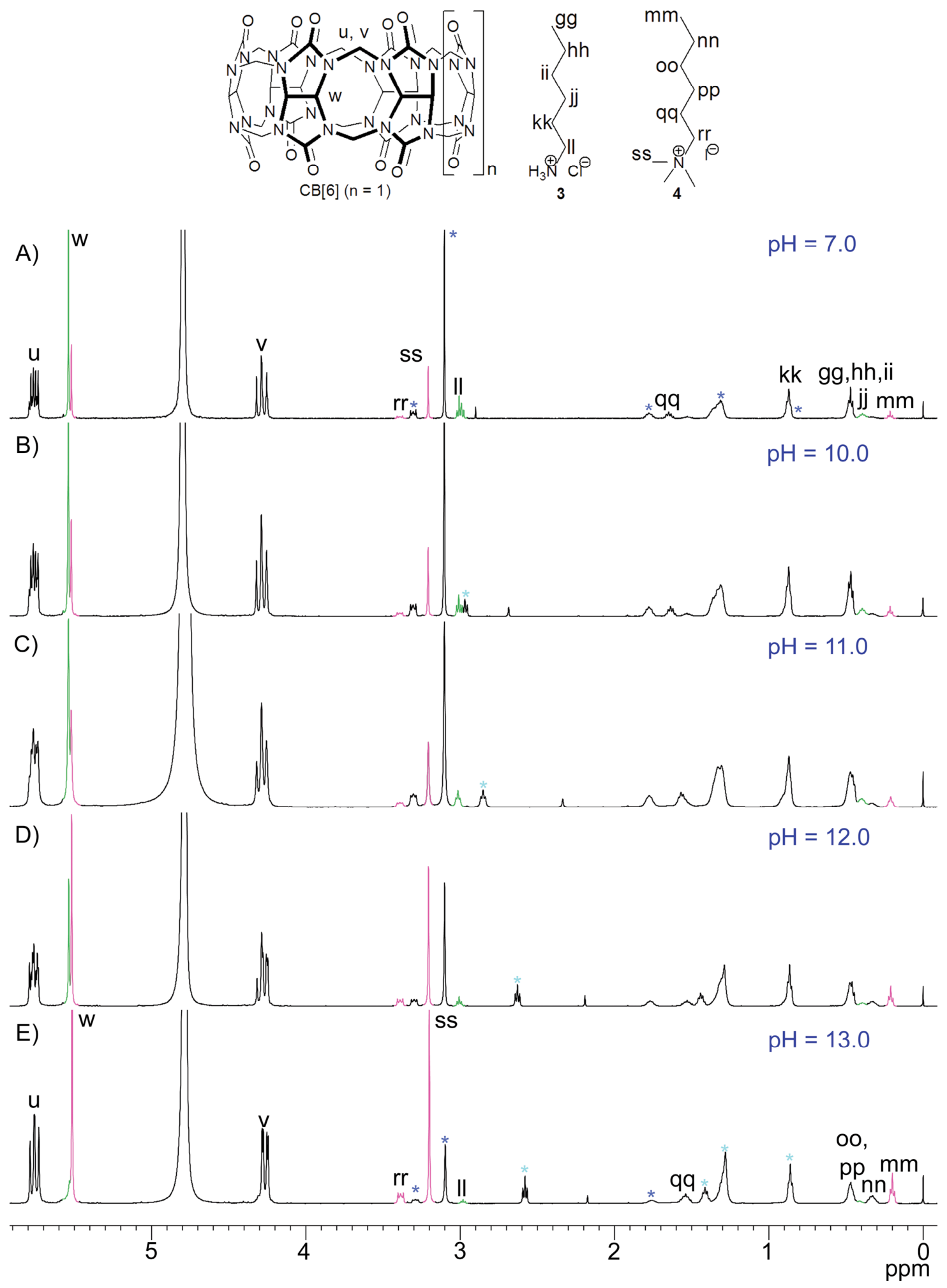

Figure S4. ${ }^{1} \mathrm{H}$ NMR spectra $\left(400 \mathrm{MHz}, \mathrm{D}_{2} \mathrm{O}, 298 \mathrm{~K}, 8 \mathrm{mM} \mathrm{Na}_{2} \mathrm{SO}_{4}\right.$ ) recorded for the three component mixtures of $\mathrm{CB}[6], 3$, and $4(2.5 \mathrm{mM}: 3 \mathrm{mM}: 3 \mathrm{mM})$ : A) at $\mathrm{pH}=7.0, \mathrm{~B})$ at $\mathrm{pH}=10.0$, C) at $\mathrm{pH}=11.0, \mathrm{D})$ at $\mathrm{pH}=12.0$ and $\mathrm{E}$ ) at $\mathrm{pH}=13.0$ [' ' and ' '*'-mark indicates the resonances due to unbound 3 and $\mathbf{4}$ respectively]. 


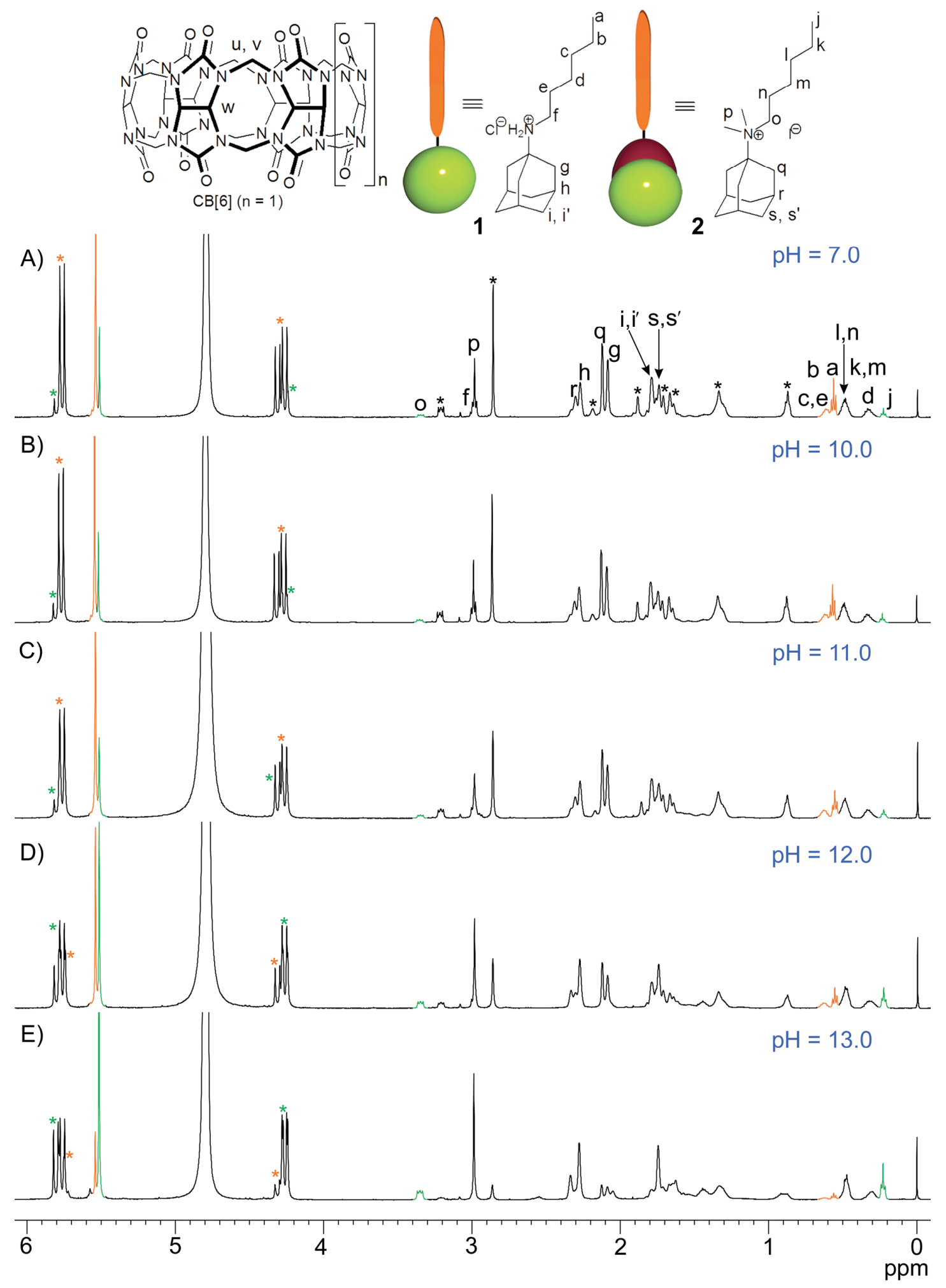

Figure S5. ${ }^{1} \mathrm{H}$ NMR spectra $\left(400 \mathrm{MHz}, \mathrm{D}_{2} \mathrm{O}, 298 \mathrm{~K}, 1.25 \mathrm{mM}\right.$ components in $8 \mathrm{mM} \mathrm{Na}_{2} \mathrm{SO}_{4}$ ) recorded for three component mixtures of $\mathrm{CB}[6], 1$ and 2 : A) at $\mathrm{pH}=7.0, \mathrm{~B}$ ) at $\mathrm{pH}=10.0, \mathrm{C}$ ) at $\mathrm{pH}=11.0, \mathrm{D})$ at $\mathrm{pH}=12.0$ and $\mathrm{E}$ ) at $\mathrm{pH}=13.0$ ['*', '*' and '*'-mark indicates the resonances due to unbound $\mathbf{1}$ and $\mathbf{2}$, complexed $\mathrm{CB}[6] \bullet \mathbf{1}$ and complexed $\mathrm{CB}[6] \bullet \mathbf{2}$ respectively]. 

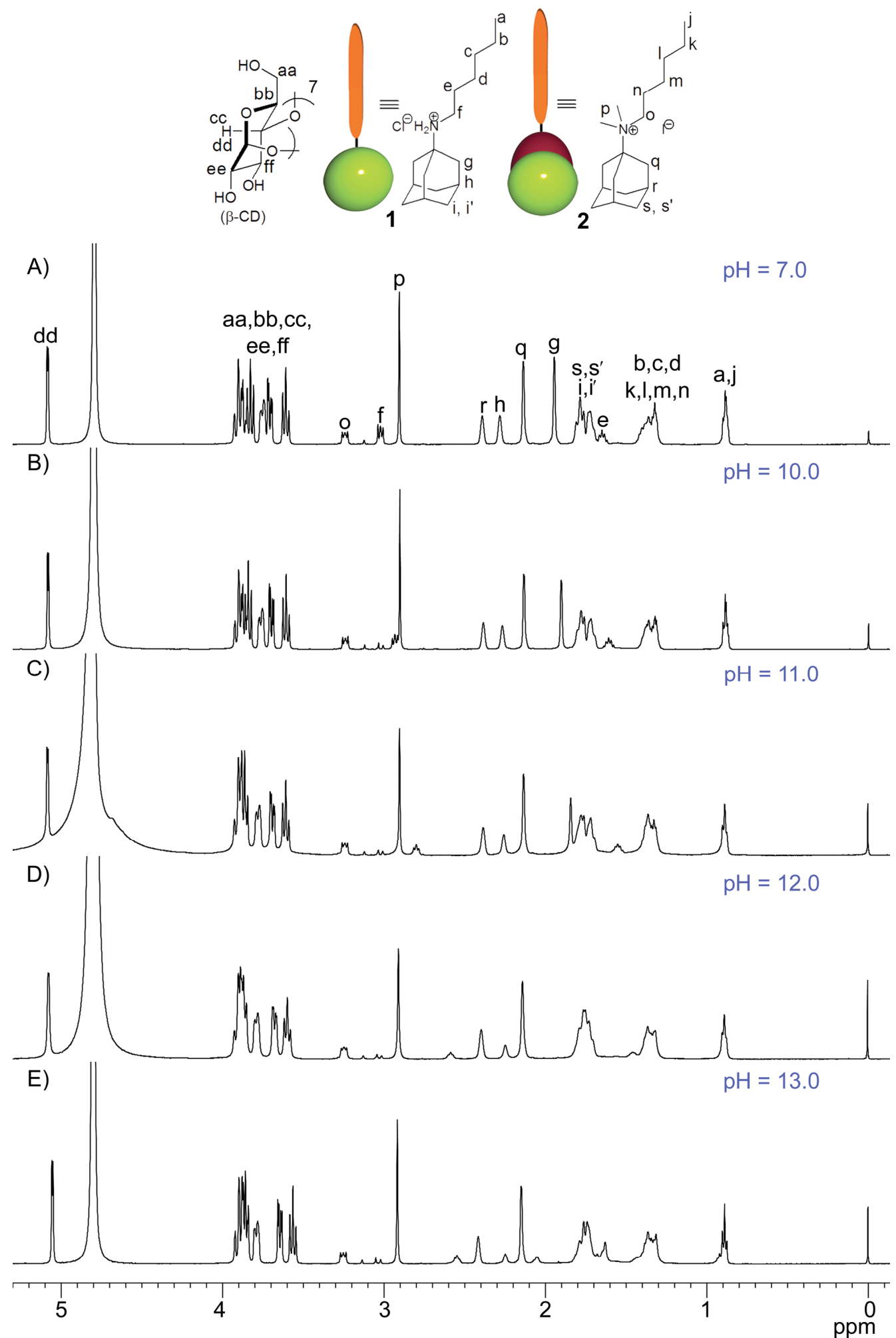

Figure S6. ${ }^{1} \mathrm{H}$ NMR spectra $\left(400 \mathrm{MHz}, \mathrm{D}_{2} \mathrm{O}, 298 \mathrm{~K}, 1.25 \mathrm{mM}\right.$ in $8 \mathrm{mM} \mathrm{Na}_{2} \mathrm{SO}_{4}$ ) recorded for three component mixtures of $\beta-\mathrm{CD}, 1$ and 2: $\mathrm{A}$ ) at $\mathrm{pH}=7.0, \mathrm{~B}$ ) at $\mathrm{pH}=10.0, \mathrm{C}$ ) at $\mathrm{pH}=11.0, \mathrm{D}$ ) at $\mathrm{pH}=12.0$ and $\mathrm{E}$ ) at $\mathrm{pH}=13.0$. 
A) $\mathrm{CB}[6]+\mathrm{GH}^{+} \stackrel{\mathrm{K}_{6 \cdot \mathrm{GH}}}{=} \mathrm{CB}[6] \cdot \mathrm{GH}^{+} \quad \beta-\mathrm{CD}+\mathrm{GH}^{+} \stackrel{\mathrm{K}_{\beta} \cdot \mathrm{GH}}{=} \beta-\mathrm{CD} \cdot \mathrm{GH}^{+} \quad$ B) $\mathrm{CB}[6]+\mathrm{GH}^{+} \stackrel{\mathrm{K}_{6} \cdot \mathrm{GH}}{=} \mathrm{CB}[6] \cdot \mathrm{GH}^{+}$ $\mathrm{CB}[6]+\mathbf{G} \quad \stackrel{\mathrm{K}_{6} \cdot \mathrm{G}}{=} \mathrm{CB}[6] \cdot \mathbf{G} \quad \beta-\mathrm{CD}+\mathbf{G} \stackrel{\mathrm{K}_{\beta} \cdot \mathrm{G}}{=} \beta-\mathrm{CD} \cdot \mathbf{G}$ $\mathrm{CB}[6]+\mathbf{G} 2 \stackrel{\mathrm{K}_{6 \cdot \mathbf{G} 2}}{\rightleftharpoons} \mathrm{CB}[6] \cdot \mathbf{G} 2 \quad \beta-\mathrm{CD}+\mathbf{G} 2 \stackrel{\mathrm{K}_{\beta} \cdot \mathbf{G} 2}{=} \beta-\mathrm{CD} \cdot \mathbf{G} 2$ $\mathrm{CB}[6]+\mathbf{G}+\mathrm{H}^{+} \stackrel{\mathrm{K}_{6 \cdot G}}{=} \mathrm{CB}[6] \cdot \mathbf{G}+\mathrm{H}^{+}$ $\mathrm{CB}[6] \cdot \mathrm{GH}^{+} \stackrel{\mathrm{K}_{6 \cdot G+\mathrm{H}}}{\rightleftharpoons} \mathrm{CB}[6] \cdot \mathbf{G}+\mathrm{H}^{+} \quad \mathbf{G H}^{+} \stackrel{\mathrm{K}_{\mathbf{G}+\mathrm{H}}}{=} \mathbf{G}+\mathrm{H}^{+}$

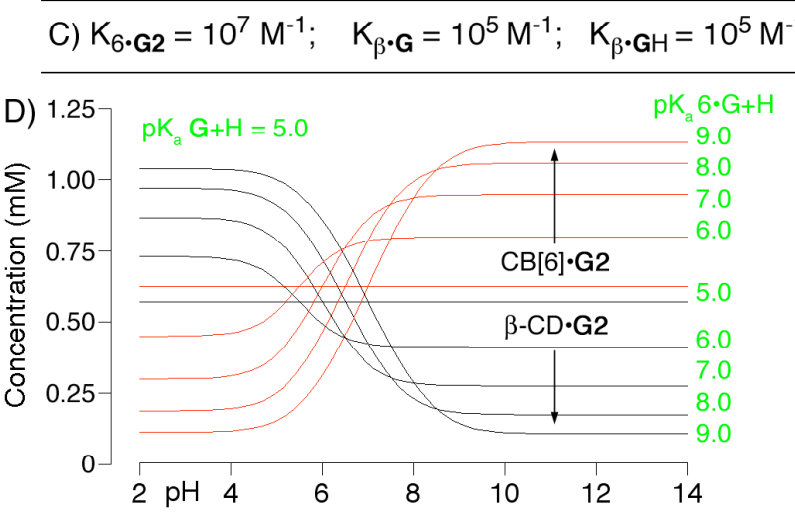

$\mathrm{K}_{\beta} \cdot \mathrm{G} 2=10^{5} \mathrm{M}^{-1} ; \log \left[\left(\mathrm{K}_{6} \cdot \mathrm{GH}\right)\left(\mathrm{K}_{6} \cdot \mathrm{G}\right)\right]=14$
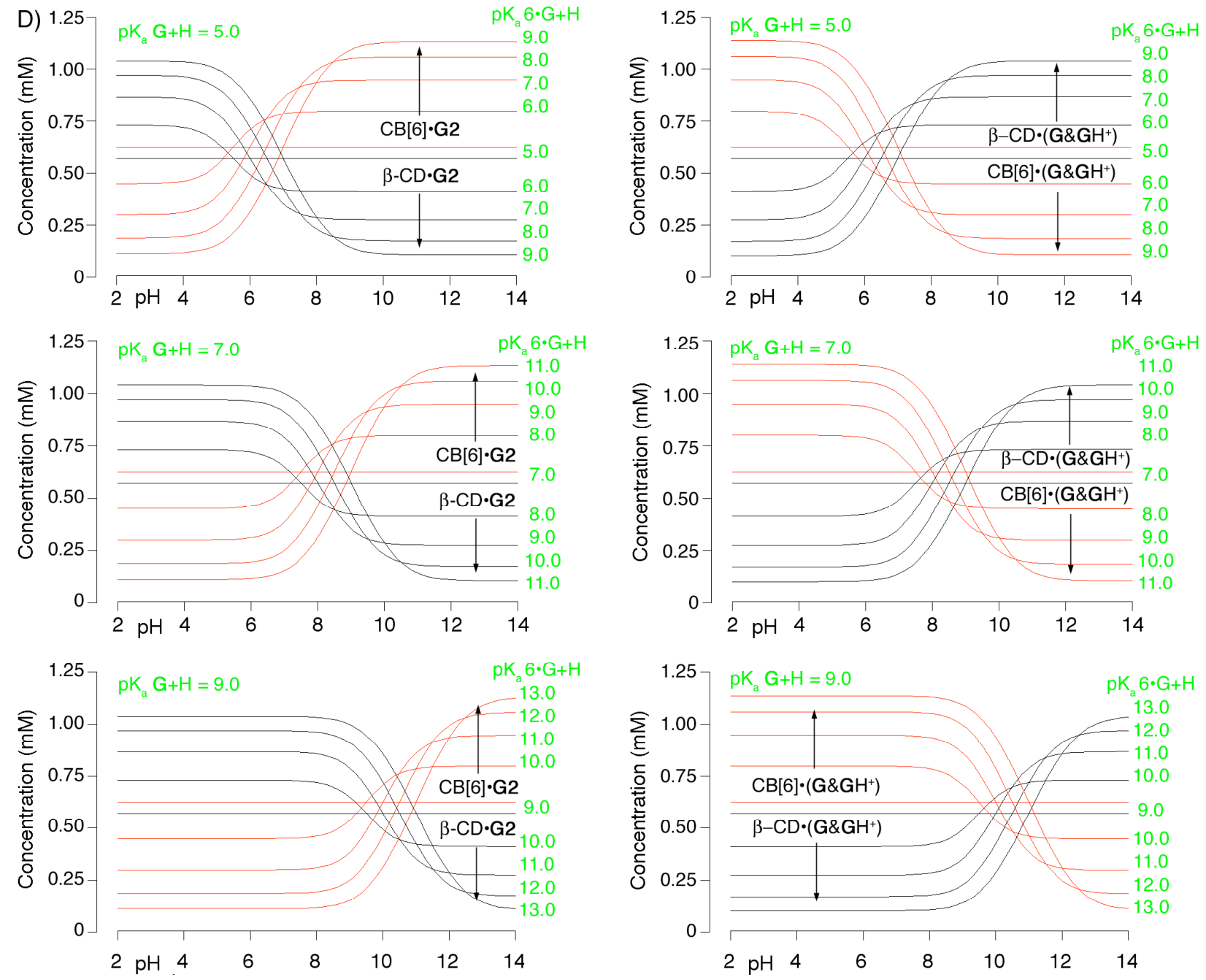

Figure S7. A) Equilibria considered, B) thermodynamic cycle for $\mathrm{CB}[6] \cdot \mathrm{G}$ complexes, C) input equilibrium constants, and D) plots of concentration versus $\mathrm{pH}(\mathrm{CB}[6]$ complexes, red lines; $\beta$ $\mathrm{CD}$ complexes, black lines) for $\mathrm{K}_{\mathbf{G}+\mathrm{H}}=10^{-5}, 10^{-7}$, and $10^{-9} \mathrm{M}^{-1}\left(\mathrm{pK}_{\mathrm{a}} \mathbf{G}+\mathrm{H}=5,7,9\right)$. The swapping curves shift to higher (lower) values of $\mathrm{pH}$ as the $\mathrm{pK}_{\mathrm{a}}$ is increased (decreased). 


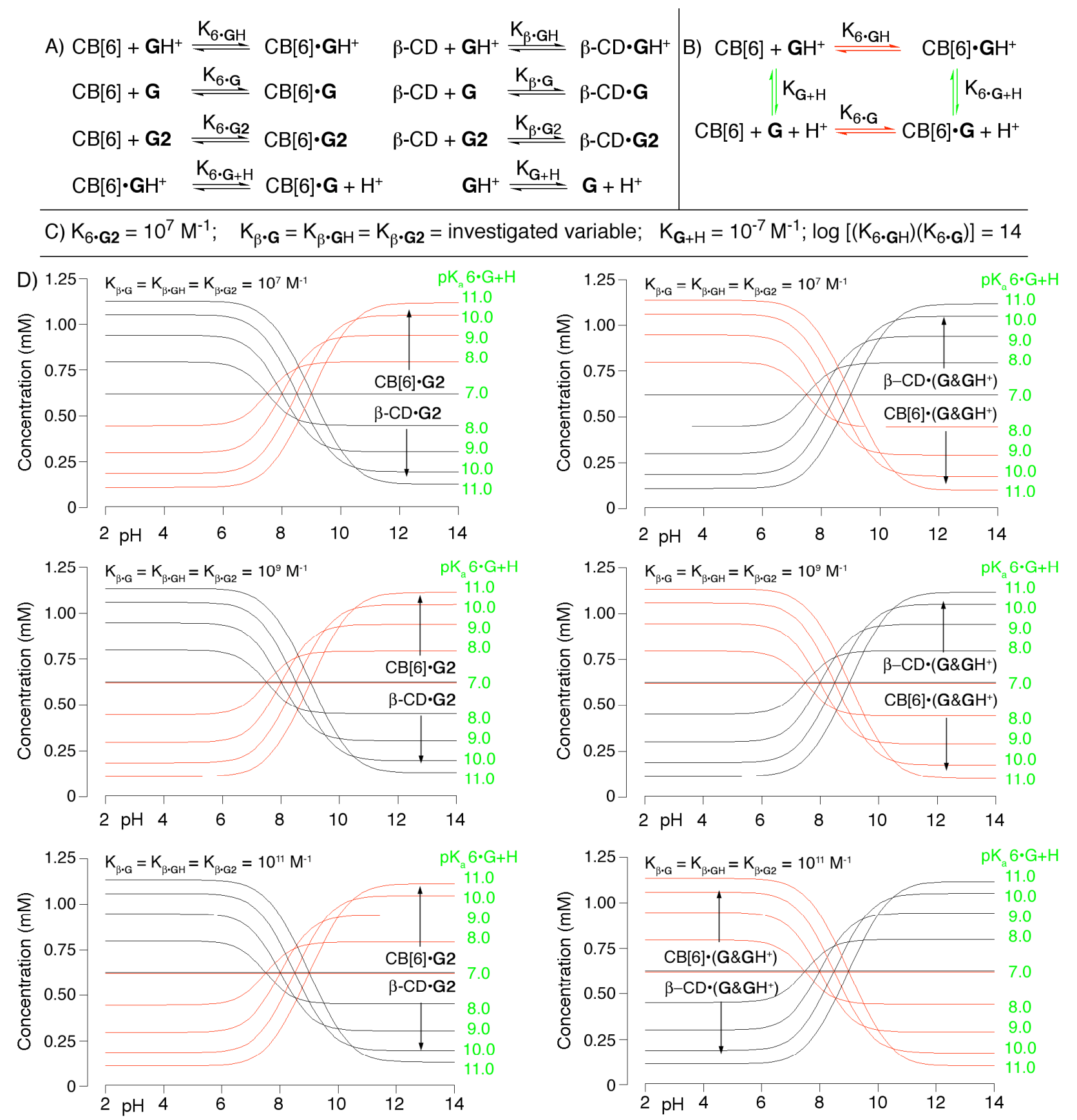

Figure S8. A) Equilibria considered, B) thermodynamic cycle for $\mathrm{CB}[6] \bullet \mathrm{G}$ complexes, C) input equilibrium constants, and D) plots of concentration versus $\mathrm{pH}(\mathrm{CB}[6]$ complexes, red lines; $\beta$ CD complexes, black lines) for $\log \mathrm{K}_{\beta \cdot \mathbf{G}}=\mathrm{K}_{\beta \cdot \mathrm{GH}}=\mathrm{K}_{\beta \cdot \mathrm{G} 2}=10^{7}, 10^{9}$, and $10^{11} \mathrm{M}^{-1}$. The swapping curves are insensitive to the binding constant for the non-pH responsive $\beta$-CD host. 


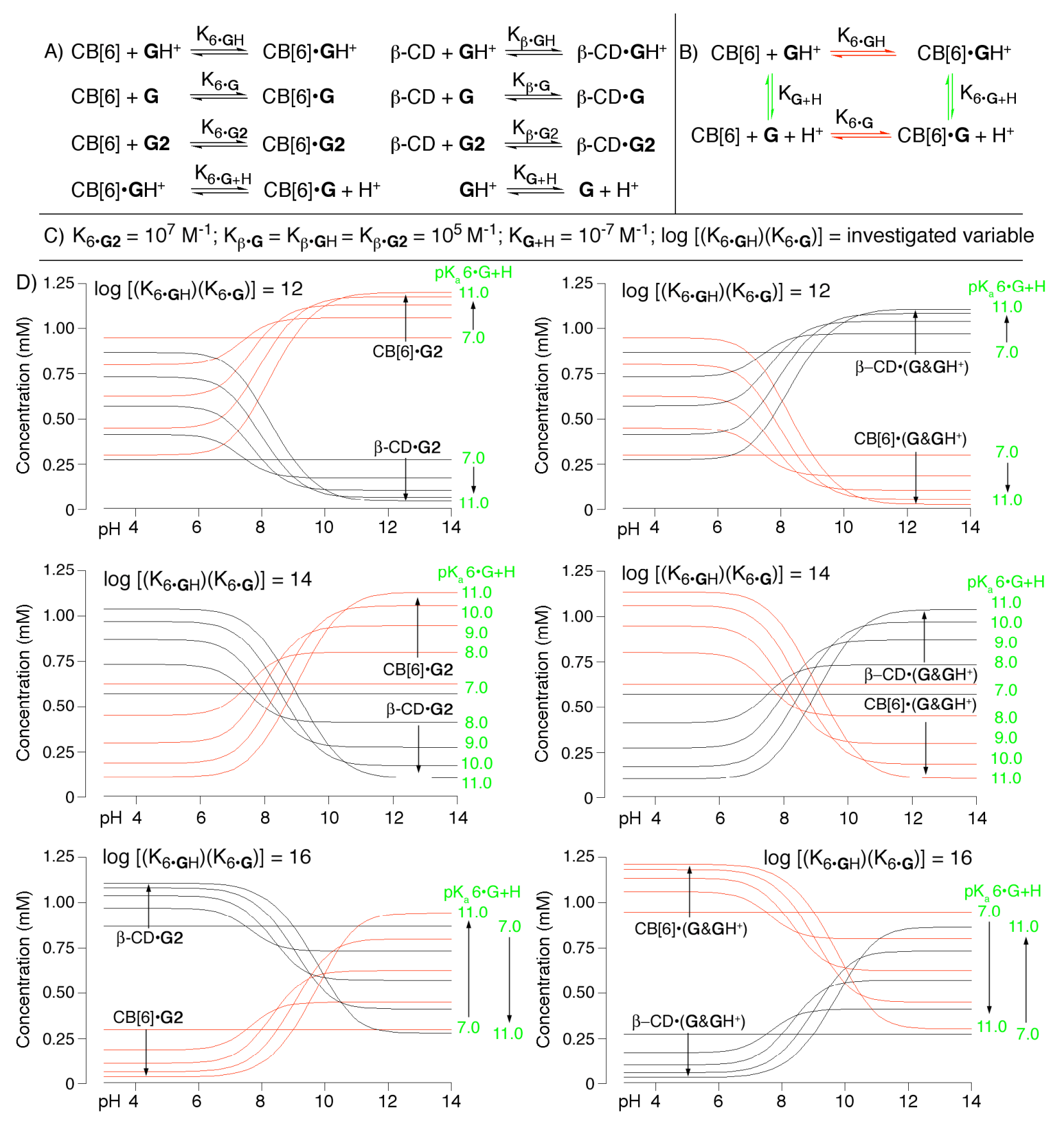

Figure S9. A) Equilibria considered, B) thermodynamic cycle for $\mathrm{CB}[6] \cdot \mathrm{G}$ complexes, C) input equilibrium constants, and D) plots of concentration versus $\mathrm{pH}(\mathrm{CB}[6]$ complexes, red lines; $\beta$ CD complexes, black lines) for $\log \left[\left(\mathrm{K}_{6 \cdot \mathbf{G H}}\right)\left(\mathrm{K}_{6 \cdot \mathbf{G}}\right)\right]=12,14$, and 16 . When $\log \left[\left(\mathrm{K}_{6 \cdot \mathbf{G H}}\right)\left(\mathrm{K}_{6 \cdot \mathrm{G}}\right)\right]$ is greater (less) than 14 the swapping efficiency decreases at high (low) $\mathrm{pH}$. 
This simulation mimics the behavior of the system comprising $\mathrm{CB}[6], \beta-\mathrm{CD}, \mathbf{1}$, and $\mathbf{2}$ studied experimentally in the manuscript. The values of $\mathrm{K}_{\mathrm{a}}$ used were derived from the literature reports but adjusted so that the simulated behavior of the system matches that observed experimentally.
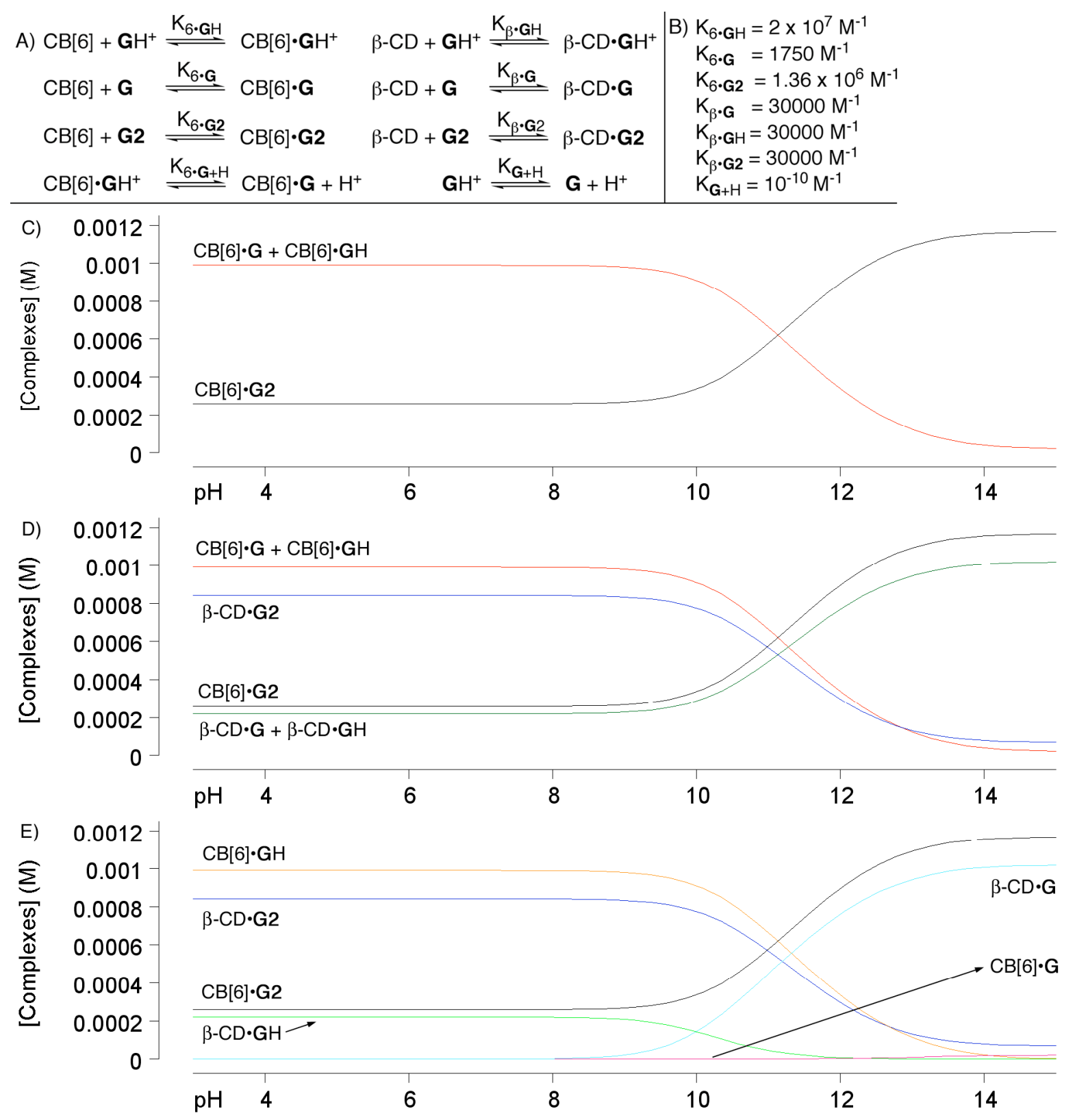

Figure S10. A) Equilibria considered, B) equilibrium constants, and several different plots of concentration versus $\mathrm{pH}$ : C) designed to mimic Figure $3 \mathrm{~B}, \mathrm{D})$ designed to mimic the pairs of plots presented in Figure S7 - S9, E) all concentrations. Initial concentrations: $[\mathrm{CB}[6]]=[\beta-\mathrm{CD}]$ $=[\mathbf{G}]=[\mathbf{G} 2]=1.25 \mathrm{mM}$. Color coding: $\mathrm{CB}[6] \bullet \mathbf{G}$, pink; $\mathrm{CB}[6] \bullet \mathbf{G H}$, orange; $\mathrm{CB}[6] \bullet \mathbf{G} 2$, black; $\beta-\mathrm{CD} \cdot \mathbf{G}$, aqua; $\beta-\mathrm{CD} \cdot \mathbf{G H}$, green; $\beta-\mathrm{CD} \cdot \mathbf{G} \mathbf{2}$, blue; $\beta-\mathrm{CD} \cdot \mathbf{G}+\beta-\mathrm{CD} \cdot \mathbf{G H}$, green; $\mathrm{CB}[6] \cdot \mathbf{G}+$ $\mathrm{CB}[6] \cdot \mathbf{G H}$, red. 